\title{
Pemberdayaan masyarakat dalam membangun ketahanan pangan keluarga sebagai materi video edukasi di masa pandemi Covid-19
}

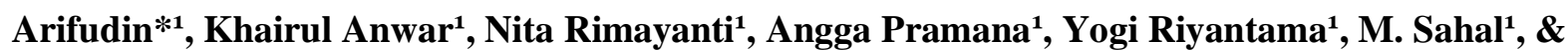 \\ Ahmad Haitami ${ }^{2}$
}

${ }^{1}$ Universitas Riau

${ }^{2}$ Universitas Islam Kuantan Singingi

* arifudin@lecturer.unri.ac.id

\begin{abstract}
Abstrak. Ketahanan pangan keluarga selama masa pandemic covid 19, melalui pemanfaatan pekarangan, dapat dilakukan oleh masyarakat secara mandiri, salah satunya melalui teknologi hidroponik. Namun demikian, pemahaman masyarakat tentang teknologi hidroponik, khususnya di Pekanbaru masih terbatas. Oleh sebab itu dibutuhkan pendampingan langsung di masyarakat, sebagai bentuk kegiatan pemberdayaan masyarakat. Kegiatan tersebut dapat diperluas melalui video edukasi yang menarik. Kegiatan pemberdayaan masyarakat dalam membangun ketahanan keluarga bertujuan untuk meningkatkan pengetahuan dan katerampilan masyarakat tentang teknologi hidroponik covid19 selama masa pandemi, dan diharapkan menjadi usaha ekonomi skala rumah tangga pasca pandemi. Kegiatan pengabdian masyarakat ini dilakukan dengan cara pelatihan dan pendampingan, serta pembuatan video untuk disebarkan secara luas melalui media sosial. Hasil dari kegiatan pengabdian menunjukkan peningkatan pengetahuan dan keterampilan masyarakat dalam melakukan budidaya tanaman dengan teknologi hidroponik. Pasca pelatihan, masyarakat secara mandiri menerapkan teknologi hidroponik, dan membentuk grup hidroponik. Proses tersebut didokumentasikan dalam bentuk video edukasi yang bermanfaat bagi masyarakat luas di Kota Pekanbaru.
\end{abstract}

Kata kunci: pemberdayaan masyarakat, hidroponik, ketahanan pangan keluarga, Covid-19, video edukasi

\begin{abstract}
Household's Food security during the Covid 19 pandemic, through the use of yards, can be conducted by the community independently such as hydroponic. However, people's understanding of hydroponic, especially in Pekanbaru, is still limited. Therefore, training for the community is needed as a community empowerment. These activities can be expanded through interesting educational videos. This community empowerment activity aims to increase community knowledge and skills regarding hydroponic technology during the pandemic, and is expected to become a post-pandemic household-scale economic enterprise. This community service activity is carried out by means of training and mentoring, as well as making a video to be widely disseminated through social media. The results of the community service activities show an increase in community knowledge and skills of hydroponic. After the training, the community independently has been aplicating hydroponic technology and biulding hydroponic group. This process is documented as educational video which is useful for the wider community in Pekanbaru City.
\end{abstract}

Keywords: community empowerment, hydroponics, family food security, Covid 19, educational videos

To cite this article: Arifudin., K. Anwar., N. Rimayanti., A. Pramana., Y. Riyantama., M. Sahal., \& A. Haitami. 2020. Pemberdayaan masyarakat dalam membangun ketahanan pangan keluarga sebagai materi video edukasi di masa pandemi Covid 19. Unri Conference Series: Community Engagement 2: 58-65. https://doi.org/10.31258/unricsce.2.58-65

(C) 2020 Authors

Peer-review under responsibility of the organizing committee of Seminar Nasional Pemberdayaan Masyarakat 2020 


\section{PENDAHULUAN}

Pada tahun 2020, dunia mengalami wabah virus yang berbahaya yang disebut dengan Covid-19. Wabah tersebut dimulai dari Wuhan, sebuah kota di Republik Rakyat Tiongkok. Virus covid-19 menyebabkan infeksi saluran pernapasan, sangat beresiko bagi pasien dengan penyakit bawaan yang dapat menyebabkan kematian. Virus ini semakin menyebar di dunia, temasuk Indonesia. Pemerintah Indonesia melakukan berbagai upaya, terutama pemberlakuan protokol kesehatan yang harus dipatuhi selama pandemi tersebut berlangsung. Masyarakat dihimbau untuk selalu menggunakan masker, mencuci tangan, dan mejaga jarak, serta menghindari kerumunan. Pembatasan sosial, baik berskala besar, maupun skala kecil juga diterapkan. Akibatnya, aktifitas masyarakat lebih banyak di rumah.

Aktifitas harian masyarakat di rumah, harus diisi dengan serangkaian kegiatan positif, seperti membangun ketahanan pangan keluarga dengan optimalisasi pekarangan yang dimiliki, terutama di Kota Pekanbaru, dimana warga lebih banyak tinggal di perumahan dengan lahan yang terbatas. Kegiatan ini harus simultan dengan upaya membangun kesadaran masyarakat untuk menerapkan kebiasaan menggunakan masker, mencuci tangan, dan menjaga jarak. Oleh sebab itu, perlu mengemas kegiatan pengabdian masyarakat yang bertujuan membangun kesadaran untuk membiasakan memberlakukan protocol kesehatan, sekaligus membangun ketahanan pangan keluarga.

Kota Pekanbaru merupakan salah satu wilayah yang menerapkan pembatasan sosial dalam untuk menerapkan protocol kesehatan. Namun selama masa pandemi masih banyak masyarakat yang tidak mematuhi aturan tersebut. Rendahnya kesadaran dan kebosanan untuk tetap tinggal di rumah menyebabkan ketidaktertiban masyarakat. Selain itu, akses akan pangan mengancam rumah tangga, akibat terhambatnya distribusi pangan dari wilayah sumber pangan, yang juga memberlakukan pembatasan sosial secara ketat. Persoalan ini dapat diatasi dengan cara produksi pangan skala rumah tangga sekaligus mengisi waktu yang bagi masyarakat yang lebih berdiam di rumah.

Kegiatan budidaya pertanian dengan menerapkan teknologi hidroponik dinilai paling cocok bagi masyarakat yang memiliki keterbatasan lahan. Hal ini merupakan bentuk pengenalan, dan penerapan, dan pengembangan ilmu pengetahuan dan teknologi kepada masyarakat. Dengan adanya pengetahuan teknologi hidroponik, diharapkan masyarakat dapat tetap produktif dalam masa pandemi. Proses pemberdayaan masyarakat akan lebih bermanfaat dengan mengemasnya dalam bentuk video edukasi yang menarik, sehingga memiliki dampak yang lebih luas bagi masyakat.

Pemberdayaan masyarakat adalah upaya memberikan daya kepada masyarakat, agar mereka mau dan mampu dalam melakukan aktifitas positif yang bermanfaat bagi mereka. Perberdayaan masyarakat memerlukan orang luar, sebagai fasilitator, sebagai pendamping yang mengikuti setiap tahapan dalam proses menuju keberdayaan masyarakat. Pemberdayaan adalah proses menyeluruh, suatu proses aktif antara fasilitator dan kelompok masyarakat yang perlu diberdayakan melalui peningkatan pengetahuan, keterampilan, pemberian berbagai kemudahan serta peluang untuk mencapai akses sistem sumberdaya dalam meningkatkan kesejahteraan masyarakat (Zuliyah, 2010).

Proses pemberdayaan meliputi enabling, menciptakan suasana kondusif, empowering, penguatan kapasitas dan kapabilitas masyarakat, protecting perlindungan dari ketidakadilan, supporting bimbingan dan dukungan dan foresting, memelihara kondisi yang kondusif tetap seimbang. Pada gilirannya diharapkan akan terwujud kapasitas ketahanan masyarakat secara lebih bermakna, bukan sebaliknya bahwa stimulan dan proses yang ada menjebak masyarakat pada suasana yang penuh ketergantungan (Bahri, 2013). Kegiatan pemberdayaan masyarakat melalui kegiatan budidaya tanaman menggunakan teknologi hidroponik sudah dilakukan oleh berbagai pihak, seperti kegiatan yang dilakukan kepada kelompok PKK Desa Pagarawan Kecamatan Merawang, Kabupaten Bangka, Provinsi Kepulauan Bangka Belitung pada tahun 2018 (Mustikarini, Santi and Inonu, 2019). Begitu juga dengan pelatihan hidroponik yang dilakukan oleh Kegiatan pengabdian masyarakat di Desa Sidudadi, Kabupaten Tulung Agung Jawa Tengah (Nugraha, 2019)

Budidaya tanaman dengan teknologi hidroponik memiliki berbagai keunggulan dibandingkan dengan budidaya tanaman konvensional. Secara umum, hidroponik merupakan salah satu alternatif budidaya tanaman memperoleh hasil produksi yang lebih baik dari segi kualitas, kuantitas, dan memiliki margin yang cukup besar (Novitasari et al., 2020; Indriasti, 2013). Pengalaman penulis berbudidaya tanaman hidroponik, menunjukkan bahwa nutrisi $\mathrm{AB}$ Mix yang mengandung unsur makro dan mikro yang dibutuhkan tanaman hidroponik dapat langsung diserap sempurna dan lebih penting waktu panen lebih cepat. Selain itu, keuntungan budidaya tanaman hidroponik diantaranya lebih mudah untuk mengendalikan serangan hama dan penyakit, pupuk dan air lebih efisien, lebih bersih dan steril, nutrisi tanaman disesuaikan dengan kebutuhan, dapat diusahakan di 
mana saja dengan lahan yang terbatas, seperti pekarangan, dan tidak bergantung pada musim (Tallei, Rumengan and A.Adam, 2017; Mulyaningsih, Mukmin and Brawijaya, 2019). Penerapan hidroponik untuk pekarangan rumah dapat dilakukan dan mejadi solusi bagi ketahanan pangan keluarga. Proses kegiatan tersebut akan mendapatkan manfaat lebih luas, jika dikemas dalam bentuk video edukasi yang menarik dan dapat ditampilkan diperluas manfaatnya di media-media sosial. Dalam pembuatan video tersebut dibutuhkan tahapan, pra produksi, produksi, dan pasca produksi (Rimayanti et al., 2019).

Kegiatan pemberdayaan masyarakat dalam membangun ketahanan keluarga bertujuan untuk meningkatkan pengetahuan dan katerampilan masyarakat tentang teknologi hidroponik, sehingga dapat memenuhi pangan keluarga selama masa pandemi, dan diharapkan dalam jangka panjang dapat menjadi usaha ekonomi skala rumah tangga pasca pandemic covid 19.

\section{METODE PENERAPAN}

\section{Metode Kegiatan}

Secara umum pemberdayaan masyarakat dalam membangun ketahanan pangan keluarga sebagai materi video edukasi di masa pandemi covid 19 kegiatan ini dilaksanakan melalui pelatihan dan pendampingan kepada masyarakat, digambarkan dalam tahapan, sebagai berikut.

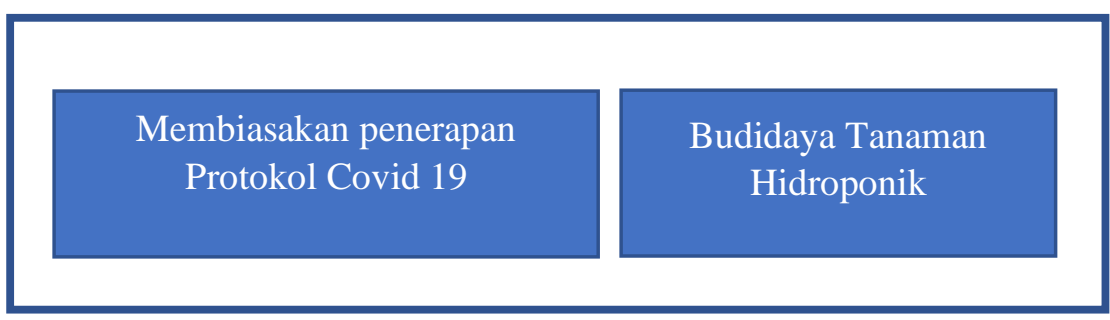

Video Edukasi Ketahanan Pangan Keluarga di Masa Pandemi
Sasaran pada kelompok Masyarakat di RW XI, Tangkerang Labuai, Bukit Raya, Pekanbaru

Publik di Media Sosial

Gambar 1. Metode Kegiatan

Metode Pengukuran Tingkat Ketercapaian

Tabel 1. Metode Pengukuran Tingkat Ketercapaian

\begin{tabular}{cll}
\hline No & Kriteria Pengukuran & Cara Mengukur \\
\hline 1 & Partisipasi & Jumlah masyarakat yang terlibat \\
2 & Kesesuaian Materi & Materi dibutuhkan oleh masyarakat \\
3 & Penerapan & $\begin{array}{l}\text { Adanya penerapan teknologi hidroponik oleh masyarakat } \\
\text { secara swadaya }\end{array}$ \\
& & Adanya aktifitas lanjutan, baik rumah tangga maupun \\
4 & Keberlanjutan & kelompok pasca kegiatan pemberdayaan \\
\hline
\end{tabular}

\section{HASIL DAN KETERCAPAIAN SASARAN}

Secara umum proses kegiatan yang telah dilakukan dalam kegiatan pemberdayaan masyarakat dalam membangun ketahan pangan keluarga, yaitu: (1) Mengkomunikasikan rencana program kepada kelompok sasaran; (2) Membangun kemitraan, sebagai komitmen pelaksanaan; (3) Menyepakati jadwal pelaksanaan bersama kelompok masyarakat (4) Menyiapkan materi dan bahan-bahan yang akan digunakan dalam pelatihan (5) Melaksanakan kegiatan pelatihan, baik teori maupun praktik tentang cara membuat dan merawat tanaman hidroponik; (6) Mendampingi kelompok masyarakat yang bersedia menerapkan teknologi hidroponik (7) 
Merekam setiap aktifitas yang dilakukan bersama masyarakat dalam bentuk video, sebagai materi edukasi yang dapat disebar luarkan.

Dari pelaksanaan kegiatan yang telah dilakukan, dapat dinilai bahwa kelompok ibu-ibu adalah kelompok yang paling strategis sebagai sasaran kegiatan pemberdayaan masyarakat. Oleh sebab itu, kelompok Ibu-Ibu sangat tepat menjadi sasaran utama dalam kegiatan pengabdian budidaya hidroponik di masyarakat. Meskipun demikian, kelompok bapak-bapak juga berminat mengembangan tanaman hidroponik di pekarangan rumah masing-masing. Kelompok bapak-bapak lebih pragmatis mempertanyakan keuntungan dari budidaya tanaman dengan teknologi hidroponik. Sedangkan kelompok ibu-ibu lebih tekun mempelajari hidroponik untuk diterapkan langsung di pekarangan rumah masing-masing

Upaya peningkatan pengetahuan dan keterampilan masyarakat, dimulai dengan kegiatan pelatihan berupa penyampaian teori, demonstrasi, dan sekaligus praktik cara pembuatan tanaman hidroponik. Dalam proses penyampaian materi, peserta selalu diingatkan untuk menerapkan protokol kesehatan, dengan selalu mencuci tangan dengan fasilitas yang disediakan, menggunakan masker yang telah dipersipakan tim pengabdian, dan selalu menjaga jarak selama pelaksanaan pelatihan yang berada pada ruang terbuka.

Secara umum, materi yang disampaikan dalam pelatihan ini adalah tentang konsep umum pertanian secara hidroponik, alat dan bahan sebagai media tanam hidroponik, jenis-jenis tanaman yang dapat dibudidayakan dengan teknologi hidroponik persemaian, penanaman, pemberian dan mengatur nutrisi tanaman, merawat tanaman, penggunaan alat TDS, dan memanen. Khusus pada tahap pemanenan, dilakukan setelah 20 hari masa tanam, dimana tanaman Kangkung dinilai mudah tumbuh dan sangat digemari oleh masyarakat.

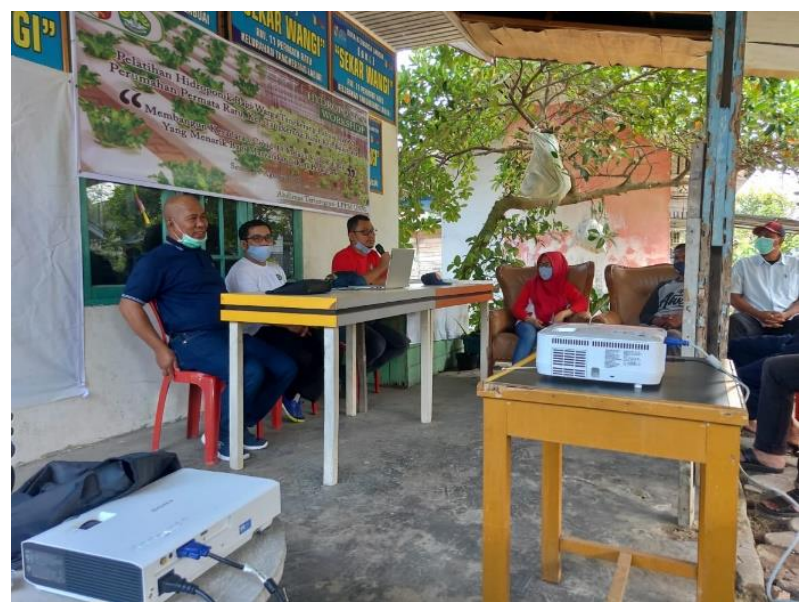

Gambar 2. Penjelasan Umum tentang perlunya Membangun Ketahanan Pangan Keluarga

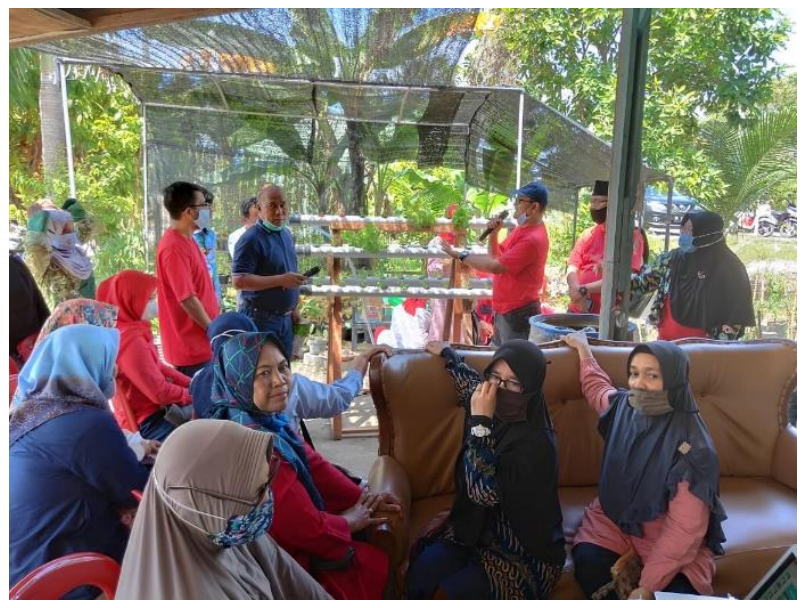

Gambar 3. Demontrasi Media Tanam Hidroponik 


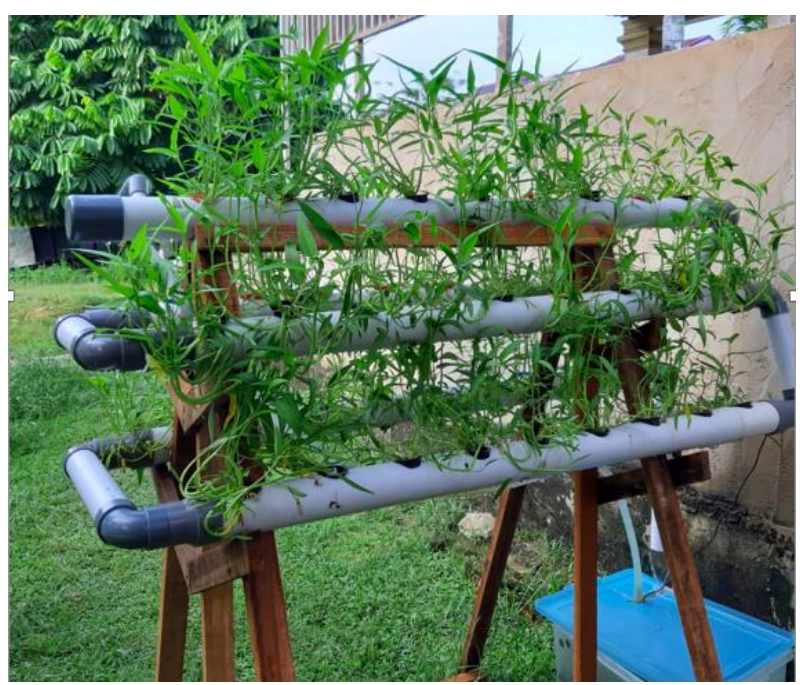

Gambar 4. Tanaman Hidroponik Siap Panen

Selain itu, yang terpenting dari kegiatan pelatihan adalah keberlanjutan. Dalam pemberdayaan masyarakat ini, telah terbentuk kelompok Hidroponik permata Ratu yang cukup aktif berkomunikasi melalui media sosial. Tim pendamping dan anggota kelompok hidroponik aktif berdiskusi dan membangun semangat penguatan ketahanan pangan keluarga melaui grup tersebut.

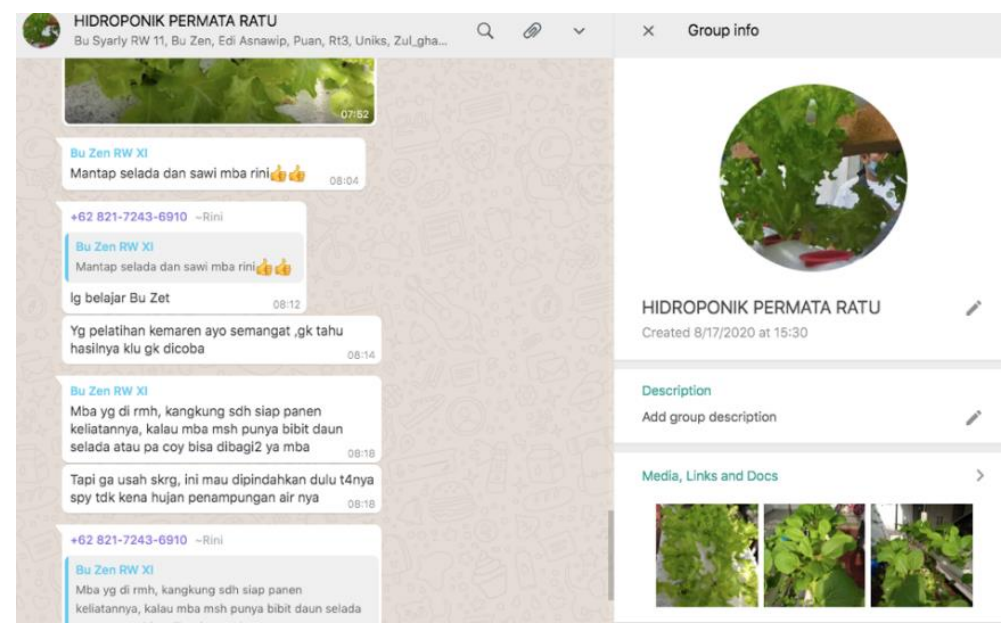

Gambar 4. Aktifitas Group di Sosial Media

\section{Tahapan Produksi dan Pascaproduksi Video Edukasi}

Pada tahapan produksi, untuk menghasilkan gambar dan suara sesuai dengan keinginan penulis naskah, maka pada tahap ini harus dilakukan berbagai kegiatan, meliputii rembuk naskah penentuan tim produk, casting, hunting lokasi shooting, rapat tim produksi, dan pengambilan gambar. 


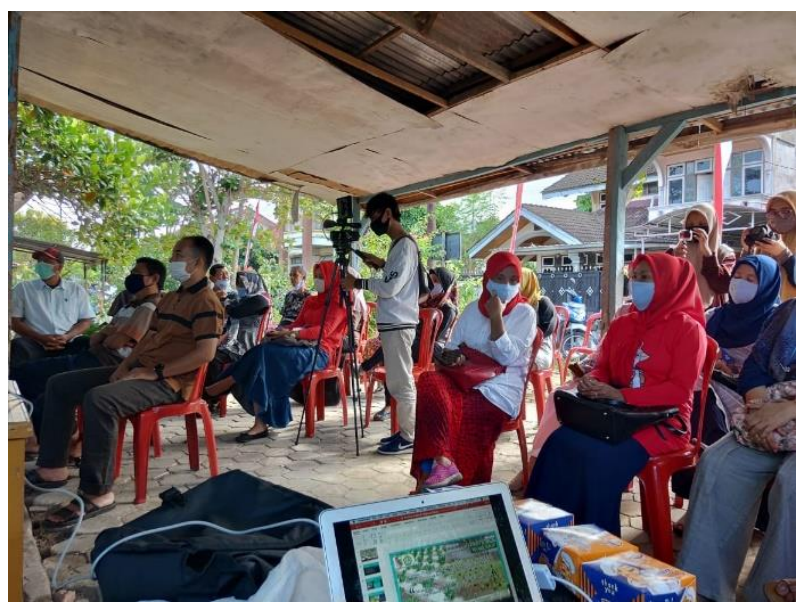

Gambar 5. Proses Produksi Video Pelatihan

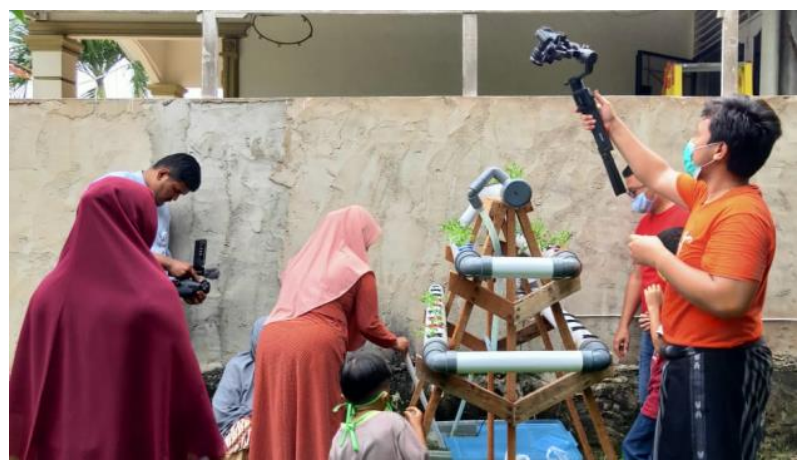

Gambar 6. Proses Produksi Video ketika panen

Setelah sekumpulan gambar dan suara diterima oleh editor, maka langkah selanjutnya yaitu tahap pemilihan gambar dan suara yang terbaik. Gambar dan suara tersebut kemudian disambung-sambung. Tahap ini cukup panjang, yaitu meliputi: penggabungan dan pemilihan gambar, mixing, preview, ujicoba, revisi, dan distribusi. hasil akhir dari kegiatan adalah sebuah media video yang menarik yang dapat disimak melalui chanel youtube: https://www.youtube.com/watch?v=wsw0SCufCCs\&fbclid=IwAR1PZM0fLGOOg4xFGBVI9UOIQxW6fS1iBR0UGS _pughe255FVvaKUMcifi4. Setelah diupload ke media youtube, terdapat ratusan orang yang menonton video tersebut. 

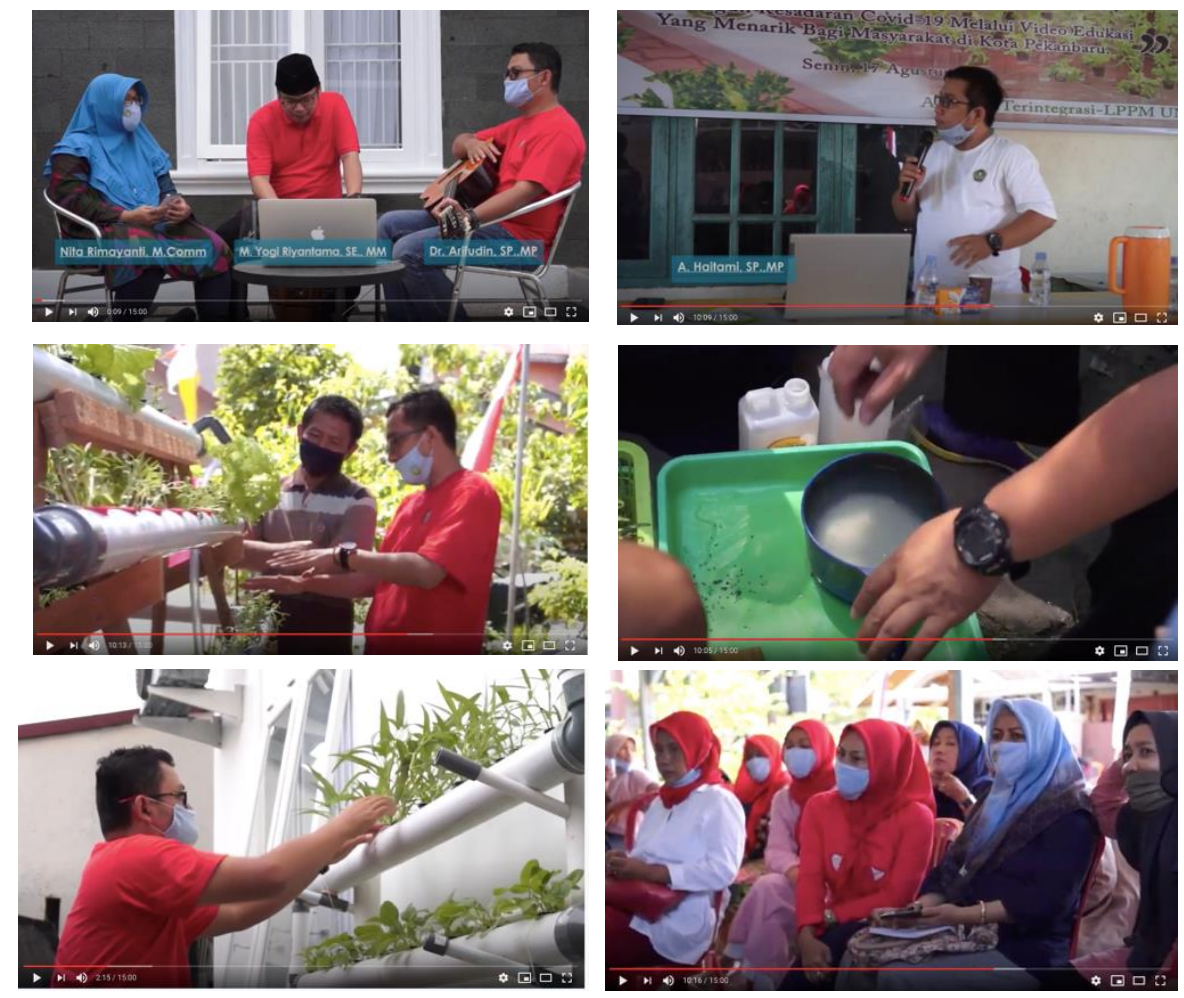

Gambar 7. Beberapa adegan dalam video edukasi ketahanan pangan keluarga

Tabel 2. Perubahan yang terjadi di masyarakat

\begin{tabular}{lll}
\hline No & Kriteria Pengukuran & Ketercapaian \\
\hline 1 & Partisipasi & $\begin{array}{l}\text { Terdapat } 30 \text { orang warga yang terlibat dalam pelatihan, dan 18 orang yang } \\
\text { terlibat aktif di dalam kelompok hidroponik }\end{array}$ \\
2 & Kesesuaian Materi & $\begin{array}{l}\text { Masyarakat merasakan bahwa materi budidaya hidroponik sangat cocok } \\
\text { bagi warga yang tinggal di Perumahan }\end{array}$ \\
& Pasca pelatihan, sebagian warga menerapkan budidaya hidroponik di \\
& pekarangannya masing-masing \\
4 & Keberlanjutan & $\begin{array}{l}\text { Pasca pelatihan, dan program pengabdian masyarakat dilakukan, warga } \\
\text { membetuk kelompok group hidroponik dalam bentuk sosial media dan } \\
\text { terus berkonsultasi aktif dalam penerapan hidroponik. }\end{array}$ \\
& &
\end{tabular}

Secara umum kegiatan-kegiatan yang direncanakan dalam pengabdian masyarakat dapat tercapai dengan baik, sesuai dengan tujuan kegiatan pengabdian kepada masyarakat.

Keunggulan dari kegiatan pemberdayaan masyarakat dalam membangun ketahanan pangan keluarga ini adalah teknologi yang diperkenalkan kepada masyarakat ini sangat mudah untuk dilakukan, dan sangat dibutuhkan masyarakat dalam waktu luang membatasi aktifitas sosial. Sedangkan kelemahannya, masyarakat masih selalu diingatkan dalam pelatihan untuk menjaga jarak, sesuai dengan protocol kesehatan yang berlaku. Oleh sebab itu, pendampingan dengan menggunakan teknologi informasi dan komunikasi dengan cara mengirimkan contoh-contoh praktek terbaik dalam penerapan teknologi, dinilai lebih efektif untuk memberikan pemahaman kepada masyarkat. Tim pengabdian juga harus menjaga komunikasi yang baik dengan masyarakat, agar konsisten untuk menerapkan budidaya hidroponik dalam rangka membangun ketahanan pangan keluarga. Pengemasan materi dalam bentuk video akan mempermudah penyebarluasan materi, namun dibutuhkan biaya yang cukup besar, jika dilakukan dengan lebih rapi dengan property yang lebih lengkap. 


\section{KESIMPULAN}

Hasil dari kegiatan pengabdian menunjukkan terjadi peningkatan pengetahuan dan keterampilan masyarakat dalam melakukan budidaya tanaman dengan teknologi hidroponik. Pasca pelatihan, masyarakat secara mandiri menerapkan teknologi hidroponik, dan membentuk grup hidroponik. Proses tersebut didokumentasikan dalam bentuk video edukasi yang bermanfaat bagi masyarakat luas di Kota Pekanbaru. Hambatan yang ditemui adalah keberlajutan pendampingan agar masyarakat tetap memiliki semangat untuk berbudidaya tanaman hidroponik dan stimulus program agar masyarakat yang berminat mau memulai berbudidaya tanaman hidroponik. Oleh sebab itu, program ini dapat dilakukan secara terus menerus sampai kepada skala usaha rumah tangga, hingga menjamurnya kampung atau perumahan hidroponik di Kota Pekanbaru.

\section{UCAPAN TERIMA KASIH}

Tim Penulis mengucapkan terimakasih kepada LPPM UNRI yang telah mendanai pelaksanaan kegiatan pengabdian kepada masyarakat. Terimakasih juga disampaikan kepada Satgas Siaga Bencana UNRI dan Warga Perumahan Permata Ratu RW XI, Tangkerang Barat, Bukit Raya, Pekanbaru atas kerjasamanya.

\section{DAFTAR PUSTAKA}

Bahri, E.S. 2013. Pemberdayaan. Kediri: FAM Publishing.

Indriasti,R. 2013. Analisa Usaha Sayuran Hidroponik pada PT Kebun Sayur Segar. Institut Pertanian Bogor.

Mulyaningsih,Y., Mukmin, M. and Brawijaya, A. 2019. Hidroponik Skerwoll dan Faedah Pekarangan Rumah Untuk Pertanian dengan Menerapkan Konsep Hidroponik Nyaman di Hati dan Kantong. Qordhul Hasan, 5(2), 107-114.

Mustikarini, E.D., Santi, R. and Inonu, I. 2019. Pemberdayaan PKK Desa Pagarawan melalui Budi Daya Tanaman Sayuran dengan Sistem Hidroponik (Empowerment of PKK Pagarawan Village through Cultivation Vegetables with Hydroponics Systems). Agrokreatif, 5(3), 173-180.

Novitasari,D., Naila, R., Syarifah, K., Pertanian, J.T., Pertanian, F., Soedirman, U.J., Agroteknologi, J., Pertanian, F. and Soedirman, U.J. 2020. Analisis kelayakan finansial budidaya selada dengan hidroponik sederhana skala rumah tangga. SEPA, 17(1), 19-23.

Nugraha,A.W. 2019. Pemberdayaan Masyarakat Desa Sumberdadi dengan Pelatihan Hidroponik dan Pupuk Organik Aldila Wanda Nugraha. JPP IPTEK, 3(1), 25-32.

Rimayanti,N., Yulianti, A., Nasution, B. and Lubis, E.E. 2019. Pembuatan Video Profil Lembaga Penelitian dan Pengabdian Universitas Riau sebagai Media Promosi Berbasis Multimedia. ITRJRD, 3(2), 84-95.

Tallei, T., Rumengan, I.F.M. and A. Adam, A. 2017. Hidroponik untuk Pemula. LPPM Universitas Sam Ratulangi.

Zuliyah,S. 2010. Strategi pemberdayaan masyarakat desa dalam menunjang pembangunan daerah. Journal of Rural and Developemnt, I(2), 151-160. 